\section{Herstmonceux castle sold but not to the highest bidder}

\section{London}

Herstmonceux castle, for 40 years the home of the Royal Greenwich Observatory, was sold last week to a British property developer for between $£ 7$ and $£ 10$ million, more than double original estimates of the site's value. The exact price paid has not been disclosed.

Possible plans for the site, which includes parkland, an observatory and offices, as well as the castle, now include a conference centre, hotel, private residences, a golf course and a science centre for the public. James Developments, the new owner, outbid a group of researchers who planned to transform the site into a science centre. The group, led by Professor Richard Gregory of the University of Bristol, raised $£ 7$ million with the help of Irving Abrams, a Canadian businessman.
When that was beaten, they made an increased offer of $£ 14$ million. But the rules of the sale meant that that bid, made after the original closing date for offers, could not be accepted. Gregory is now negotiating with the developer with a view to securing part of the site for his plans.

Ian Tegg, managing director of the developer, says he is looking for "bright people with bright ideas" to determine the future of Herstmonceux, and says there is interest in the site from the United States, Canada and Japan as well as Britain. Whether the observatory will continue to be used or will become a museum has not yet been decided. Staff move to a new building in Cambridge in 1990. The move will cost about $£ 7$ million and will be financed by the sale. Funds remaining will go to the Treasury.

Christine McGourty

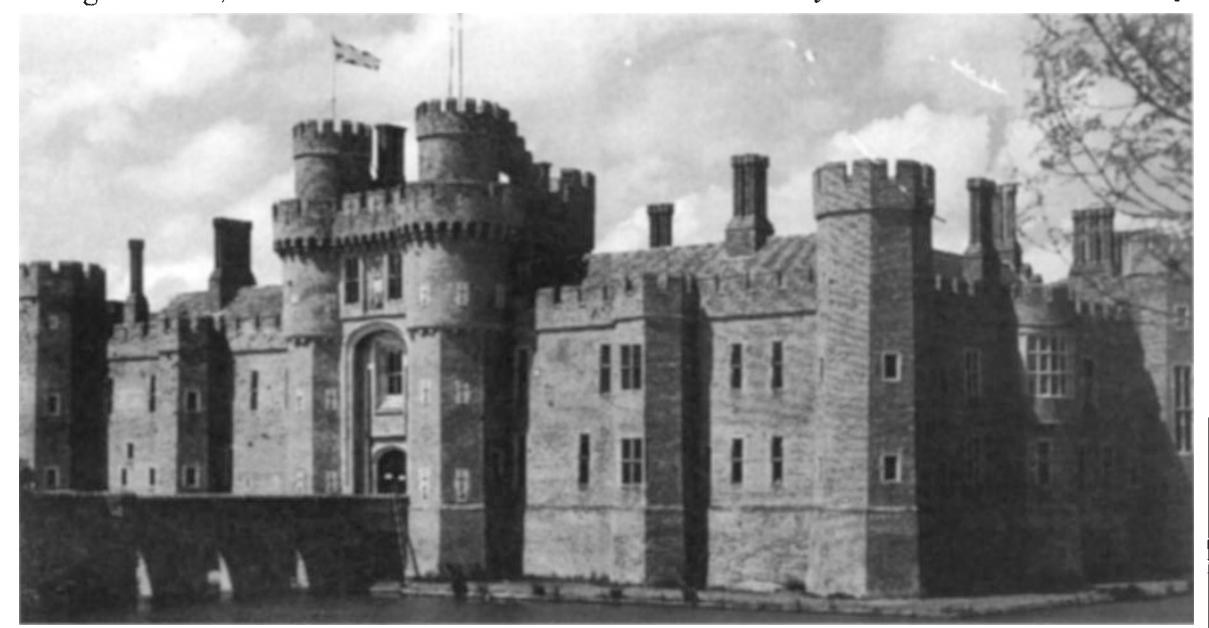

Herstmonceux castle - into an unknown future.

\section{French government already under attack}

\section{Paris}

THE socialist French government is experiencing its most troubled period since it was elected last spring. By refusing to give in to demands for pay rises in the public sector, the government has angered teachers and nurses whose interests the socialist party claims to represent.

While thousands of public sector employees, especially nurses, teachers and those in nationalized industries, protested in the streets of Paris last week, the government faced the possibility that its 1989 budget would be thrown out if 'centrists' joined with the right-wing opposition. But although Prime Minister Michel Rocard is accused of squandering the nation's newfound wealth, the budget increase in research spending has been applauded on both sides of the assembly.

The government has been accused of 'anti-Europeanism' by the right-wing opposition because of its resistance to tampering with the tax structure. To fall in line with other European countries from 1992, France will have to reduce its rates of value-added tax (VAT). But increased revenue from VAT during 1987 was an important factor in the new government's ability to reverse its predecssors' demands for belt-tightening in higher education and research. Now it looks as though the finance minister, Pierre Bérégovoy, will have to reduce VAT on luxury goods, but Rocard hopes to stall the European project to introduce a uniform fiscal structure.

The most delicate series of debates will be held this week as the budgets of individual ministries are scrutinized. It is likely that the government will leave the most controversial ministries to last, including education, in the hope of winning centre support in time for a single vote to approve the budgets en bloc.

\section{Telescopes get the green light}

\section{Washington}

Tre University of Arizona will have a new observatory in its backyard, thanks to a law passed in the final days of this congressional session. As part of the Arizona-Idaho Conservation Act of 1988 , the university will be allowed to build three telescopes on one of the 11,000-foothigh peaks of Mount Graham, in southeastern Arizona.

The law ends an often contentious fourand-a-half-year evaluation and environmental assessment of the university's plans by the US Forest Service, the federal agency charged with managing the mountain. The new legislation will make it extremely difficult for opponents of the observatories to delay or prevent their construction.

The law allows three telescopes - the Columbus Project, a Vatican telescope and the Max Planck sub-millimetre telescope and their accompanying support facilities - to be built on 24 acres of Emerald Peak, subject to conditions outlined by the US Fish and Wildlife Service (see Nature 334, 645; 1988).

The fate of four additional telescopes sought by the university will depend on how the endangered Mount Graham red squirrel fares during the initial construction phase, according to Patty Lynch, legislative assistant for Senator Dennis DeConcini (Democrat, Arizona).

The new legislation on the observatories was a late addition to a bill that authorized several land transfers, including the acquisition by the federal government of 100,000 acres of Florida Everglades wetlands.

Scientists for the Preservation of Mount Graham, a group of about 100 biologists, many of whom had worked on the mountain, opposes any observatory development because the peaks represent a unique "desert sky island" of sub-alpine spruce and fir.

As part of the law, the university must develop and fund a conservation management plan in conjunction with federal agencies. "The University of Arizona will be a responsible steward", said Allan Beigel, vice-president for university relations. "We see ourselves as having linked hands with responsible environmentalists."

But opponents of the university's plans vow to continue the fight. "We're going to try to stop the addition of four more telescopes", says Paul Hirt, local Sierra Club representative and spokesman for the Coalition for the Preservation of Mount Graham. He also vowed that the coalition would be a watchdog to make sure the university sticks to its authorized plans.

Elizabeth Pennisi 